\title{
Clear skies, dark waters: The Gulf oil spill and the price of coastal condominiums in Alabama
}

\author{
Christy Siegel $^{1} \cdot$ Steven B. Caudill $^{2} \cdot$ Franklin G. Mixon, Jr. ${ }^{3^{*}}$ \\ ${ }^{1}$ Imperial College London, London, United Kingdom \\ ${ }^{2}$ Rhodes College, Memphis, Tennessee, United States \\ ${ }^{3}$ Columbus State University, Columbus, Georgia, United States
}

Received: 1 March 2013

Revised: 12 May 2013

Accepted: 14 May 2013

\begin{abstract}
This study focuses on the effect on real estate prices of the oil spill in the Gulf of Mexico in 2010. Based on previous studies on the effects of water contamination on real estate, it is likely that this oil spill, which was not capped for three months, had a drastic effect on real estate prices. Using data on condominium prices in Orange Beach and Gulf Shores, Alabama, from January 2009 to September 2011, a before-and-after econometric test suggests that there was a 12.1 percent decline in condominium sale prices (per square foot) after the oil spill, while additional tests indicate a decline of 10.1 percent to 13.5 percent in sale prices (per square foot) over the first 100 days after the spill. Lastly, any significant negative price effects due to the spill appear to have dissipated by 101 days after the spill.
\end{abstract}

Keywords: economics of disasters, real estate economics, resource economics JEL Classification Codes: H23, L85, P48, Q25, Q53, R21

\section{Introduction}

In 2010, the largest accidental marine oil spill in the history of the petroleum industry occurred in the Gulf of Mexico when British Petroleum's Deepwater Horizon offshore oil well exploded on 20 April, killing 11 rig workers. Almost 200 million gallons of crude oil escaped into the water over a period of three months before the well was finally capped, forcing British Petroleum (BP) and the U.S. government to oversee the use of more than 1.8 million gallons of chemical dispersants, 770,000 of which were deployed at the source near the ocean floor, to deal with the problem that threatened the marine ecology of a vast area of the Gulf of Mexico

\footnotetext{
*Corresponding author. E-mail: mixon_franklin@ columbusstate.edu.

Citation: Siegel, C., S.B. Caudill and F.G. Mixon Jr (2013) Clear skies, dark waters: The Gulf oil spill and the price of coastal condominiums in Alabama, Economics and Business Letters, 2(2), 42-53.
} 
(Associated Press, 2012). Massive damages to marine and wildlife habitats, and fishing and tourism industries, occurred as a result of the oil spill, and some of the effects of the spill are only now coming to light. For example, Raines (2012) reports that after the spill, the Gulf's oyster harvest was down about 40 percent due to fishing closures; even so, 2010 ranked as one of the deadliest years on record in terms of illnesses from consumption of oysters tainted with Vibrio vuinificus bacteria. Oceanic scientists have estimated, and the Food and Drug Administration has agreed, that such bacteria levels in the Gulf were elevated at least 100-fold after the oil spill (Raines, 2012). ${ }^{1}$ As a result of these and other issues related to the safety of oil dispersant chemicals, a coalition of environment and public health groups that includes the Sierra Club and the Louisiana Shrimp Association is suing the U.S. Environmental Protection Agency (EPA) over standards for future use of such chemicals (Alpert, 2012).

Based on prior research on the economics of disasters, it is possible that the environmental contamination due to the spill had a negative effect on the prices of condominiums alongside the Gulf of Mexico. In fact, some scholars refer to events emanating from natural disasters (e.g., a hurricane) and man-made disasters (e.g., the Deepwater Horizon oil spill) as unannounced information events or accelerated information cascades (Salter and King, 2009) that produce such negative economic consequences. Studies examining the effect of natural disasters on real estate prices abound. These include studies on the impact of California's Loma Prieta earthquake in 1989 (Shelor, Anderson and Cross, 1990; Murdoch, Singh and Thayer, 1993), Hurricane Andrew in 1992 (Hallstrom and Smith, 2005), California's Northridge earthquake in 1994 (Bleich, 2003), Hurricane Floyd in 1999 (Bin and Polasky, 2004; Graham, Hall and Schuhmann, 2007; Burrus, Graham, Hall and Schuhmann, 2009), and Hurricane Katrina in 2005 (Salter and King, 2009). Specifically, Murdoch, Singh and Thayer (1993) find that the Loma Prieta earthquake caused a San Francisco-area wide reduction in property values, while Hallstrom and Smith (2005) find that Hurricane Andrew led to a 19 percent decline in property values in hurricane prone areas of Florida. ${ }^{2}$

Additionally, several seminal studies in this genre have examined the effect of air and water quality, and even more specifically the effect of utility siting, on real estate prices (e.g., Ridker and Henning, 1967; David, 1968; Blomquist, 1974; Deyak and Smith, 1974; Harrison and Rubinfeld, 1978; McClelland, Shulze and Hurd, 1990; Hellerstein, Huguenin, Unsworth and Brazee, 1992; Dale, Murdoch, and Waddell, 1999). However, the rarity of disasters of the magnitude of the Deepwater Horizon oil spill has provided (fortunately) few opportunities for study by academics. This study examines the impact of the unannounced information event represented by the 2010 Gulf oil spill, which affected a large area of the northern portion of the Gulf of Mexico. Particularly hard hit was the southern coastline of Alabama, where the major tourist destinations of Gulf Shores and Orange Beach are located. As the map in the Appendix indicates, projections on 7 June 2010 showed that a large swath, a majority in fact, of the spilled oil would ultimately settle along the Alabama coastline, adversely affecting the market for condominiums in both Gulf Shores and Orange Beach.

\footnotetext{
${ }^{1}$ Dauphin Island Sea Lab scientists in Alabama have stated that the oil in the Gulf amounted to a prime food source for microbes such as Vibrio vuinificus, which multiplied due to the massive food source. Scientists from Auburn University have documented exceptionally high levels of vibrio bacteria in tar balls (Raines, 2012).

${ }^{2}$ Relatedly, Shelor, Anderson and Cross (1990) examine the impact of the earthquake on real estate-related stock prices and find that the impact of the earthquake was reflected in statistically significant negative real estate-related stock returns among those firms operating in the San Francisco area, while real estate-related firms operating in other areas of California were generally unaffected by the earthquake.
} 
The results presented in this study are based upon 2,500 real estate transactions involving condominiums in both Gulf Shores and Orange Beach over the 33-month period from January 2009 to September 2011. This time frame allows for analysis of the impact of the oil spill by including sales transactions data before, during, and after the spill. Our results indicate that there was a decrease in condominium prices of about $\$ 29,500$, ceteris paribus, or roughly $\$ 25$ per square foot, after the oil spill. Thus, some of the negative economic shocks that can be traced to the Gulf oil spill in 2010 have been material to many full- and part-time residents along the Alabama coastline.

\section{A brief review of the literature}

A common theme of recent literature on the economic effects, particularly in housing markets, of man-made disasters has been that of petroleum pipeline ruptures. An example of this is the study by Simons, Winson-Geideman and Mikelbank (2000), which investigates the effects of a pipeline rupture in Prince George County, Maryland, on residential property values. Data from 2,300 single-family house sales surrounding the Patuxent River in Maryland, both before and after the rupture, were employed. These data included both waterfront property and nonwaterfront property, and indicated that waterfront home prices declined 11 percent within the six months following the pipeline rupture. In a similar study examining the effect of a pipeline accident on real estate prices, Hansen, Benson and Hagen (2006) posit that there are substantial price effects on residential property following a pipeline accident; as expected, however, these price effects diminish the greater the distance the property is located from the accident. Using a sample of single family home sales, Hansen, et al. (2006) estimate the marginal willingness-topay for distance from the pipeline based on data collected before and after the 1999 pipeline rupture in Bellingham, Washington. ${ }^{3}$ The results from this study suggest that there is a significant negative effect on residential property prices from the accident, with the sales price of the houses falling from 0.2 percent to 4.6 percent, depending on the proximity to the accident. Similarly, Zabel and Guignet (2011) examine the price effects of petroleum leakage from underground storage tanks (LUSTs) on the sales of single family homes in three Maryland counties from 1996 to 2007 . This study focuses on determining willingness to pay for housing farther from the contaminated sites, and it estimates the decrease in home values located closer to LUST sites. ${ }^{4}$ The authors find that the typical LUST site is unlikely to have significant impacts on housing prices, although their findings do show that a LUST site that is well-known to the public or severely contaminated can impact nearby home values by more than 10 percent.

Two branches in the literature are especially linked to elements of the Deepwater Horizon oil spill story examined in this study. These are (1) empirical results related to the quality of water, for either recreation or food supplies, and nearby housing values, and (2) empirical results related to the 2010 Deepwater Horizon disaster, specifically. Regarding the first branch, Michael, Boyle and Bouchard (1996) examine willingness to pay for property on a lake with high water quality. To do so, they collected data on property sales from residential areas near 34 Maine lakes, separated into six separate markets based on location, from January of 1990 to June

\footnotetext{
${ }^{3}$ The timeframe of the data used ranges from five years prior to the accident to five years following the accident. Only houses within a one mile radius of the pipelines involved were used.

${ }^{4}$ The data collected contained single-family home sales information for dates before and after the discovery of the leak, along with information on contaminated areas during the same time period.
} 
of $19944^{5}$ Michael, et al. (1996) focused on poor water quality resulting from eutrophication, a situation wherein a body of water acquires a high concentration of nutrients resulting in excess algae growth. ${ }^{6}$ Their results confirm that water clarity significantly impacts property prices around Maine lakes, with average property prices per foot of lake frontage ranging from $\$ 11$ to $\$ 200$, depending on the level of water clarity. Similarly, Leggett and Bockstael (2000) focus on whether consumers are willing to pay higher residential prices for a reduction in the amount of bacteria found in nearby water. They studied areas in Maryland's Anne Arundel County, which is situated on the shore of the Chesapeake Bay and located within 40 miles of both Baltimore and Washington D.C. The particular quality issue examined by these authors is the measured amount of fecal coliform bacteria present in the Chesapeake Bay. Leggett and Bockstael (2000) find that an increase in fecal coliform counts is estimated to produce about a 1.5 percent reduction in property prices (Leggett and Bockstael, 2000: 137). ${ }^{7}$ Of course, the findings from these two studies have important implications concerning the levels of bacteria currently being found in the Gulf of Mexico as a result of the 2010 Gulf oil spill.

Turning to the second branch of the literature highlighted above, Epley (2011) provides the seminal empirical analysis of the potential loss in property value as a result of the 2010 Deepwater Horizon oil spill. Eply's analysis focuses on market trends evident from the population of recorded deeds available over three different time frames: (1) one year before the 2010 oil spill, (2) eight weeks after the 2010 oil spill, and (3) 16 weeks after the 2010 oil spill. ${ }^{8}$ More specifically, Epley (2011) examines recorded deeds from April 20, 2009, through August 15,2010 . His before-and-after approach applied to coastal Alabama properties finds no negative impact from the oil spill on either single family properties or waterfront condominiums, although he does find that vacant residential coastline properties declined in value by 16 percent.

These previous studies, particularly the latter three, provide a nice framework for examining the possibility of a negative impact on real estate prices along the Alabama coastline as a result of water contamination from the 2010 Deepwater Horizon oil spill. In terms of prior studies most directly linked to the current one, the time frame involved in Epley (2011), which ends in midAugust of 2010, while the Deepwater Horizon oil leak was not capped until mid-July of 2010, is potentially problematic. Epley's time frame spans only one month after the oil well was capped. Much of the cleanup had yet to occur by the end of his time frame, and, as pointed out in this study, much of the environmental damage in the Gulf of Mexico (e.g., bacterial growth, etc.) is only now being realized. Also, the value of Alabama coastline, particularly as a tourist/vacation destination, is perhaps better realized in the value of condominiums than in single-family dwellings. By combining the two, Epley's approach combines potentially different sets of concerns or issues. Lastly, the examination of recorded deeds, rather than examination of available real estate transactions prices, represents a departure from prior literature that may also be unnecessary. As stated above, the present study addresses these issues by directly examining transactions prices (per square foot) for condominium sales in both Gulf Shores and Orange Beach, Alabama, over a period of about 135 weeks, ending in September of 2011, or more than

\footnotetext{
${ }^{5}$ Only residential and recreational single-family, lakefront homes were included in this study.

${ }^{6}$ The eutrophication was measured through a secchi disk reading that measures the minimum clarity in the lake for the year the property was sold.

${ }^{7}$ Specifically, this study uses an increase of 100 fecal coliform counts per $100 \mathrm{~mL}$ to estimate the effect of water contamination on housing prices.

${ }^{8}$ The total time frame for recorded deeds in Epley (2011) is about 68 weeks.
} 
one year after the BP oil well was capped. The econometric approach used in our analysis is explained in the subsequent section, as are the empirical results.

\section{The economic model and econometric results}

The econometric model estimated in this study includes condominium sale prices per square feet (SPRICE/SQFT) as the dependent variable, based on almost 2,500 condominium sales in both Gulf Shores and Orange Beach, Alabama, over the period from January of 2009 to September of 2011. ${ }^{9}$ The dependent variable is specified as SPRICE/SQFT because price per square foot is commonly used by those in real estate to calculate prices. ${ }^{10}$ The time period involved in this study is evenly divided (approximately) by the event under consideration, namely the Deepwater Horizon (Gulf) oil spill of April of 2010. The complete specification of the economic model to be tested is shown in equation (1):

$S P R I C E / S Q F T=\alpha+\beta_{1} F E E S+\beta_{2} N E W+\beta_{3} O L D+\beta_{4} O R A N G E B E A C H+\beta_{5} U N E M P+\beta_{6} O I L S P I L L+\varepsilon$

Independent variables in equation (1) include FEES, which is equal to the ownership fees associated with each individual condominium sold. This variable is a nice proxy for amenities associated with the condominium complex or condominium group with which each individual condominium sold is affiliated, and may include access to swimming pool(s), clubhouse(s), parking spaces, garbage collection, and/or other recreational amenities (e.g., tennis courts, shuffle board surfaces, golf course, etc.). As with the individual condomonium's amenities, FEES is expected to be positively related, ceteris paribus, to SPRICE/SQFT.

The remaining independent variables include a set of dummy variables for each condominium's age (NEW and $O L D)$, a dummy variable for city location (ORANGEBEACH), a macroeconomic variable (UNEMP), and a dummy variable for the 2010 Gulf oil spill (OILSPILL). The dummy variable $N E W$ is equal to 1 for condominiums that are less than five years old, and zero otherwise. The dummy variable $O L D$ is equal to 1 for condominiums that are more than 10 years old, and zero otherwise. Each captures condominium price comparisons to middle-aged condominiums - those from five to 10 years old - sold. As such, we expect $N E W$ to be positively related to SPRICE/SQFT, while $O L D$ should be negatively related to $S P R I C E / S Q F T$. Next, ORANGEBEACH is a dummy variable equal to 1 for condominium sales in Orange Beach, and 0 otherwise (i.e., in Gulf Shores). This variable is included to capture differences between the two real estate markets examined in this study.

The condominium markets in both Gulf Shores and Orange Beach are national markets in the sense that buyers and sellers are dispersed throughout the United States. As such, UNEMP, which is equal to the average rate of U.S. unemployment (monthly), is included to capture the idea that many coastal condominium buyers (owners) are permanent residents of towns and cities located throughout the southeastern and eastern portions (and even beyond) of the U.S. It

\footnotetext{
${ }^{9}$ The authors thank Re-Max of Gulf Shores for providing the data used in this study. Given that our sample of condominium prices was provided by a real estate firm, our analysis is somewhat limited in that we do not include transactions completed by condominium developers or others.

${ }^{10}$ Unfortunately, our data do now allow us to classify condominiums by type so as to permit examination of the effect of the oil spill on various types of condominium dwellings. We also do not have information on whether the condominiums sampled are part of a high-rise structure or are ground-level dwellings, distinctions that would impact a potential tenant's view of the Gulf.
} 
is expected that a worsening (improving) economy would, ceteris paribus, lead to lower (higher) condominium sale prices. Thus, it is expected that UNEMP will be negatively related to SPRICE/SQFT. Lastly, our variable of interest, OILSPILL, is a dummy variable equal to 1 for condominium sales occurring after the Gulf oil spill, and 0 otherwise. Of course, if the negative externality represented by the 2010 Gulf oil spill had an impact on real estate markets along the Alabama coastline, as we posit did occur, then according to a before-and-after approach OILSPILL will, ceteris paribus, be negatively related to SPRICE/SQFT.

Descriptions of each of the variables, along with summary statistics, are included in Table 1. As shown there, the average condominium sale price per square foot is \$207, while condominium fees average $\$ 491$. The newest condominiums sold account for about five percent of the sample, and the oldest make up about 39 percent of the sample. The average (monthly) unemployment rate exhibits a mean of 9.4 percent, and the condominium sales are divided almost evenly between Gulf Shores (52 percent) and Orange Beach (48 percent). The OLS estimation results are given in the second column of Table 2. Robust standard errors are calculated for each regressor, and, based on 2,463 observations, the $R^{2}$ is 0.27 . The coefficients of the variables in the model support our expectations, and all are different from zero at the 0.05 level of significance or better. In particular, OILSPILL has a value of -25.21 , with a $t$-ratio exceeding nine (in absolute value). This result indicates an average drop in price per square foot, across all condominium sales, of about $\$ 25$ following the Gulf oil spill. Using the average condominium sale price (per square foot) of $\$ 207$, this estimate represents a price drop due to the Gulf oil spill of 12.1 percent. This result is accompanied by another indicating that an additional percentage-point increase in unemployment reduces PRICE/SQFT by about $\$ 7.16$, suggesting that the economic recession likely reduced the prices of condominiums along Alabama's coastline by about $\$ 32$ per square foot. This figure represents a drop in value of about 15.5 percent.

Table 1. Variables and Summary Statistics

\begin{tabular}{|c|c|c|c|}
\hline Variable & Description & Mean & $\begin{array}{c}\text { Standard } \\
\text { Deviation }\end{array}$ \\
\hline SPRICE/SQFT & Sale price per square foot of living space & 207.05 & 78.53 \\
\hline$N E W$ & $\begin{array}{l}\text { A dummy variable equal } 1 \text { for condominiums that are less than five } \\
\text { years old, and } 0 \text { otherwise }\end{array}$ & 0.047 & 0.21 \\
\hline$O L D$ & $\begin{array}{l}\text { A dummy variable equal } 1 \text { for condominiums that are more than } 10 \\
\text { years old, and } 0 \text { otherwise }\end{array}$ & 0.391 & 0.49 \\
\hline FEES & Amount of condo fees & 491.43 & 232.69 \\
\hline ORANGEBEACH & $\begin{array}{l}\text { A dummy variable equal to } 1 \text { if condominium is in Orange Beach, } \\
\text { and } 0 \text { otherwise }\end{array}$ & 0.48 & 0.50 \\
\hline UNEMP & Average unemployment per month & 0.094 & 0.004 \\
\hline OILSPILL & $\begin{array}{l}\text { A dummy variable equal } 1 \text { for condominium sales after the oil } \\
\text { spill, and } 0 \text { otherwise }\end{array}$ & 0.55 & 0.50 \\
\hline
\end{tabular}

Turning to some of the other results in Table 2, the amenities associated with each additional dollar of condominium complex (or condominium group) fees generates an additional $\$ 0.07$ in the condominium's per square feet sale price. Using the average condominium complex fee of $\$ 491$, complex amenities are associated with approximately $\$ 34$ per square foot price of living space. This total is an approximately 16.5 percent of the mean value of SPRICE/SQFT. Next, 
based on average results for $N E W$ and $O L D$, new condominiums are associated with a price premium of about $\$ 92$ per square foot, while old condominiums are discounted by about $\$ 16$ per square foot. These figures account for about 45 percent and eight percent of the mean value of SPRICE/SQFT. Lastly, condominiums in Orange Beach receive a sale price premium of about $\$ 27$ per square foot compared to their Gulf Shores counterparts. This premium could be due to location considerations, such as Orange Beach's proximity to the Gulf beaches in northwest Florida.

One shortcoming of the before and after modality of our approach above is that it misses some of the dynamics associated with disasters and prices. An issue here is the persistence of memory - how long does this price effect of the oil spill persist? To capture this memory, we created a series of dummy variables that account for the number of days from the disaster. The dummy variables in this series are SPILL1, SPILL2, SPILL3, . . SPILL16, and they are equal to 1 for transactions that occur during days 1-25 following the spill, days 26-50 following the spill, days 51-75 following the spill, . . . and days 201-225 following the spill, respectively, and 0 otherwise. If the effect of the event fades and condominium prices bounce back with time, as expected, then the coefficient estimates in this series are expected to increase over time.

To supplement the addition of the SPILL series, we also created a monthly dummy variables series. This series includes dummy variables for each month (i.e., JAN, FEB, MAR, etc.), with December serving as the omitted month (category) in the series. In each case, observations coded as 1 represent the respective month in the series, and 0 otherwise. Next, the original model above does not take into account interest rates or any measure of the price of credit. To account for this issue, we included MORT\%, which is the weekly average 30-year mortgage rate for the southeastern U.S. Lastly, our supplemental model replaces UNEMP with DJIA, which is a weekly average measure of the Dow Jones Industrial Average over the period under study. ${ }^{11}$ Given the mixed results in the literature regarding the relationship between (1) mortgage rates and housing prices (e.g., McGibany and Nourzad, 2004; Himmelberg, Mayer and Sinai, 2005; Mian and Sufi, 2009; Keys, Mukherjee, Seru and Vig, 2009; Glaeser, Gottlieb and Gyourko, 2010), and (2) stock returns and housing prices (e.g., Ibottson and Siegel, 1984; Liu, Hartzell, Greig and Grissom, 1990; Stone and Ziemba, 1993; Quan and Titman, 1999; Liow, 2006), the relationships between (1) MORT\% and SPRICE/SQFT, and (2) DJIA and SPRICE/SQFT are empirical questions.

Estimation results from the expanded regression model described above are presented in column three of Table 2. The results for the SPILL series indicate that the oil spill generally had a negative and statistically significant impact on condominium prices over the first 100 days following the spill. The significantly negative effect of the oil spill on condominium prices following the spill ranges from 10.1 percent to 13.5 percent. Although these percentage estimates are similar to that found from the before-and-after model (i.e., 12.1 percent), the new model points out that the price effect of the oil spill appears to have dissipated after 100 days (since the spill) have elapsed.

The monthly dummy variables series indicates that condominium prices generally increase from January to May, and are significantly higher in May, after which time they retreat until November, when they are significantly higher once again. Next, the results for FEES, NEW and $O L D$ are remarkably similar to their version one counterparts, with the first two exhibiting

\footnotetext{
${ }^{11}$ The mean and standard deviation for MORT\% from our sample are 4.817 and 0.281 , respectively, while those for DJIA are 10,471 and 1,490 , respectively.
} 
positive and statistically significant relationships to condominium prices (per square foot), while the latter variable is again negative and significant. In this case, each additional dollar of condominium complex (or condominium group) fees again generates an additional $\$ 0.07$ in the condominium's price per square foot. Using the average condominium complex fee of $\$ 491$, complex amenities are associated with an approximately $\$ 34$ price per square foot.

Table 2. Summary of Econometric Results

\begin{tabular}{|c|c|c|}
\hline Variable & SPRICE/SQFT & SPRICE/SQFT \\
\hline Intercept & $242.45 *(7.73)$ & $140.88 \dagger(2.49)$ \\
\hline FEES & $0.070 *(4.65)$ & $0.068 *(4.44)$ \\
\hline$N E W$ & $91.81 *(8.87)$ & $86.51 *(7.70)$ \\
\hline$O L D$ & $-16.13^{*}(-4.62)$ & $-16.46^{*}(-4.73)$ \\
\hline ORANGEBEACH & $26.77 *(9.42)$ & $27.62 *(9.75)$ \\
\hline UNEMP & $-715.92+(-2.28)$ & \\
\hline MORT\% & & $16.71(1.90)$ \\
\hline DJIA & & $-0.6 \mathrm{e}-2^{*}(-3.80)$ \\
\hline OILSPILL & $-25.21 *(-9.19)$ & \\
\hline SPILLI & & $-28.21 *(-2.90)$ \\
\hline SPILL2 & & $-1.07(-0.11)$ \\
\hline SPILL3 & & $-25.65 \dagger(-2.40)$ \\
\hline SPILLA & & $-21.33 \dagger(-2.17)$ \\
\hline SPILL5 & & $-13.20(-1.30)$ \\
\hline SPILL6 & & $0.13(0.01)$ \\
\hline SPILL7 & & $13.90(1.29)$ \\
\hline SPILL8 & & $-3.63(-0.37)$ \\
\hline SPILL9 & & $-17.80(-1.48)$ \\
\hline SPILL10 & & $3.01(0.25)$ \\
\hline SPILL11 & & $-12.60(-1.03)$ \\
\hline SPILL12 & & $10.13(0.92)$ \\
\hline SPILL13 & & $-10.62(-1.01)$ \\
\hline SPILL14 & & $2.07(0.22)$ \\
\hline SPILL15 & & $-16.70(-1.73)$ \\
\hline SPILL16 & & $-17.43(-1.62)$ \\
\hline$J A N$ & & $5.45(0.54)$ \\
\hline$F E B$ & & $8.04(0.82)$ \\
\hline$M A R$ & & $-3.03(-0.32)$ \\
\hline$A P R$ & & $15.79(1.67)$ \\
\hline$M A Y$ & & $27.42 *(2.77)$ \\
\hline JUN & & $10.50(1.14)$ \\
\hline$J U L$ & & $11.81(1.26)$ \\
\hline$A U G$ & & $16.76(1.74)$ \\
\hline$S E P$ & & 11.85 (1.18) \\
\hline$O C T$ & & 16.38 (1.59) \\
\hline NOV & & $21.34 \dagger(2.06)$ \\
\hline$n$ & 2,463 & 2,463 \\
\hline$R^{2}$ & 0.27 & 0.27 \\
\hline
\end{tabular}

Interestingly, MORT\% and DJIA are positively and negatively related to SPRICE/SQFT, respectively. However, only DJIA is significant at the 0.05 level or better. Next, based on average results for $N E W$ and $O L D$, new condominiums are associated with a price premium of 
about $\$ 87$ per square foot, while old condominiums are discounted by about $\$ 16$ per square foot. These figures account for about 42 percent and eight percent of the mean value of SPRICE/SQFT. Lastly, condominiums in Orange Beach receive a sale price premium of about $\$ 28$ per square foot compared to their Gulf Shores counterparts, which, as stated above, could be due to location considerations, such as Orange Beach's proximity to the Gulf beaches in northwest Florida.

\section{Concluding comments}

While oil spills are not very common, they can have a drastic impact on the economy and the environment, whether it is in relation to fishing or tourism industries, marine or wildlife habitats, or even real estate. The largest accidental oil spill in the history of the petroleum industry occurred in the Gulf of Mexico in 2010, when British Petroleum's Deepwater Horizon well exploded, dumping almost 200 million gallons of crude oil into the Gulf of Mexico over three months. This man-made disaster negatively impacted economies in the surrounding areas. Yet, while declines in the fishing or tourism industries are easily observable, it can be difficult to detect the negative effects from the oil spill in other areas, such as the real estate market.

This study engages in just such a detection process by examining, using a before-and-after approach, condominium prices in both Gulf Shores and Orange Beach (both in Alabama). Econometric results presented here indicate that the 2010 oil spill hit the real estate markets in a major way, resulting in condominium price decreases of $\$ 21$ to $\$ 28$ per square foot, depending on the time period examined. This decrease equates to a 10.1 to 13.5 percent reduction in prices in the two Gulf Coast condominium markets, augmenting substantially the already-large losses which are estimated in this study at 15.5 percent - incurred by Gulf Coast condominium owners from the weakened national economy. Finally, econometric evidence presented in this study suggests that any significant negative price effects due to the spill appear to have dissipated by 101 days after the spill.

Acknowledgements. The authors thank two anonymous referees, the Editor-in-Chief Francisco J. Delgado and Robert Feinberg for providing helpful comments on a previous version of this study. We also thank Re-Max of Gulf Shores for providing the data used in this study. The usual caveat applies.

\section{References}

Alpert, B. (2012) Environmental group sues EPA over dispersants used during Gulf oil spill, New Orleans Times-Picayune (6 August), online (www.nola.com/news/gulf-oilspill/index.ssf/2012/08/environmental_group_sues_epa_o.html), accessed on 13 August 2012.

Associated Press (2012) BP oil dispersants may have hurt Gulf of Mexico food chain, study finds, New Orleans Times-Picayune (31 July), online, (www.nola.com/news/gulf-oilspill/index.ssf/2012/07/bp_oil_spill_dispersants_may_h.html), accessed on 13 August 2012.

Bin, O. and Polasky, S. (2004) Effects of flood hazards on property values: Evidence before and after Hurricane Floyd, Land Economics, 80(4), 490-500.

Bleich, D. (2003) The reaction of multifamily capitalization rates to natural disasters, Journal of Real Estate Research, 25(2), 133-144.

Blomquist, G. C. (1974) The effect of electric utility power plant location on area property value, Land Economics, 50(1), 97-100. 
Boyle, M. A. and Kiel, K.A. (2001) A survey of house price hedonic studies of the impact of environmental externalities, Journal of Real Estate Literature, 9(2), 117-144.

Braden, J.B., Feng, X., Freitas, L. and Won, D. (2010) Meta-functional transfer of hedonic property values: Application to Great Lakes areas of concern, Agricultural and Resource Economics Review, 39(1), 101-113.

Burrus, R.T., Jr., Graham, J.E., Jr., Hall, W.W. and Schuhmann, P.W. (2009) Home-buyer sentiment and hurricane landfalls, Appraisal Journal, 77(4), 338-347.

Dale, L., Murdoch, J.C., Thayer, M.A. and Waddell, P.A. (1999) Do property values rebound from environmental stigmas? Evidence from Dallas, Land Economics, 75(2), 311-26.

David, E.L. (1968) Lakeshore property values: A guide to public investment in recreation, Water Resources Research, 4(4), 697-707.

Deyak, T.A. and Smith, V.K. (1974) Residential property values and air pollution: Some new evidence, Quarterly Review of Economics and Business, 14(4), 93-100.

Epley, D. (2012) The Gulf oil spill and its impact on coastal property value using the before-and-after procedure, Journal of Real Estate Literature, 20(1), 127-137.

Glaeser, E.L., Gottlieb, J.D. and Gyourko, J. (2010) Can cheap credit explain the housing bubble? NBER Working Paper.

Graham, J.E., Hall, W.W. and Schuhmann, P.W. (2007) Hurricanes, catastrophic risk, and real estate market recovery, Journal of Real Estate Portfolio Management, 13(3), 179-190.

Hallstrom, D.G. and Smith, V.K. (2005) Market responses to hurricanes, Journal of Environmental Economics and Management, 50(3), 541-561.

Hansen, J.L., Benson, E.D. and Hagen, D.A. (2006) Environmental hazards and residential property values: Evidence from a major pipeline event, Land Economics, 82(4), 529-41.

Harrison, D., Jr. and Rubinfeld, D.L. (1978) Hedonic housing prices and the demand for clean air, Journal of Environmental Economics and Management 5(1), 81-102.

Himmelberg, C., Mayer, C. and Sinai, T. (2005) Assessing high house prices: Bubbles, fundamentals and misperceptions, Journal of Economic Perspectives, 19(4), 67-92.

Ibbotson, R.G. and Siegel, L.B. (1984) Real estate returns: A comparison with other investments, Real Estate Economics, 12(3), 219-242.

Jackson, T.O. (2002) Environmental contamination and industrial real estate prices, Journal of Real Estate Research, 23(1/2), 179-199.

Keys, B.J., Mukherjee, T., Seru, A. and Vig, V. (2009) Financial regulation and securitization: Evidence from subprime mortgage loans, Journal of Monetary Economics, 56(5), 700-720.

Leggett, C.G. and Bockstael, N.E. (2000) Evidence of the effects of water quality on residential land prices, Journal of Environmental Economics and Management, 39(2), 121-144.

Liow, K.H. (2006) Dynamic relationship between stock and property markets, Applied Financial Economics, 16(5), 371-376.

Liu, C.H., Hartzell, D.J., Greig, W. and Grissom, T.V. (1990) The integration of the real estate market and the stock market: Some preliminary evidence, Journal of Real Estate and Finance Economics, 3(3), 261-282.

McClelland, G.H., Schulze, W.D. and Hurd, B. (1990) The effect of risk beliefs on property values: A case study of a hazardous waste site, Risk Analysis, 10(4), 485-497.

McGibany, J.M. and Nourzad, F. (2004) Do lower mortgage rates mean higher housing prices? Applied Economics, 36(4), 305-313.

Mendelsohn, R., Hellerstein, D., Huguenin, M., Unsworth, R. and Brazee, R. (1992) Measuring hazardous waste damages with panel models, Journal of Environmental Economics and Management, 22(3), 259-71.

Mian, A. and Sufi, A. (2009) The consequences of mortgage credit expansion: Evidence from the U.S. mortgage default crisis, Quarterly Journal of Economics, 124(4), 1,449-1,496. 
Michael, H.J., Boyle, K.J. and Bouchard, R. (1986) Water quality affects property orices: A case study of selected Maine lakes, Maine Agricultural and Forest Experiment Station, University of Maine, Miscellaneous Report 398.

Murdoch, J.C., Singh, H. and Thayer, M. (1993) The impact of natural hazards on housing values: The Loma Prieta earthquake, Real Estate Economics, 21(2), 167-184.

Quan, D.C. and Titman, S. (1999) Do real estate prices and stock prices move together? An international analysis, Real Estate Economics, 27(2), 183-207.

Raines, B. (2012) Levels of deadly bacteria more than 100 times higher in Gulf waters during the BP spill, The Mobile Press-Register (27 July), online, (http://blog.al.com/live/2012/07/levels_of_deadly_bacteria_more.html\#incart_river_default), accessed on 27 July 2012.

Ridker, R.G. and Henning, J.A. (1967) The determinants of residential property values with special reference to air pollution, Review of Economics and Statistics, 49(2), 246-57.

Salter, S.P. and King, E.W. (2009) Price adjustment and liquidity in a residential real estate market with an accelerated information cascade, Journal of Real Estate Research, 31(4), 421-454.

Shelor, R.M., Anderson, D.C. and Cross, M.L. (1990) The impact of the California earthquake on real estate firms' stock value, Journal of Real Estate Research, 5(3), 335-340.

Simons, R.A., Winson-Geideman, K. and Mikelbank, B.A. (2001) The effects of an oil pipeline rupture on single-family house prices, The Appraisal Journal, 69(4), 410-18.

Steinnes, D. N. (1992) Measuring the economic value of water quality, Annals of Regional Science, 26(2), 171-76.

Stone, D. and Ziemba, W.T. (1993) Land and stock prices in Japan, Journal of Economic Perspectives, 7(3), 149-165.

Zabel, J. and Guignet, D. (2011) A hedonic analysis of the impact of LUST sites on house prices, Unpublished Manuscript. 
Appendix. Map of Northeast Gulf of Mexico Showing Oil Spill Path Projection

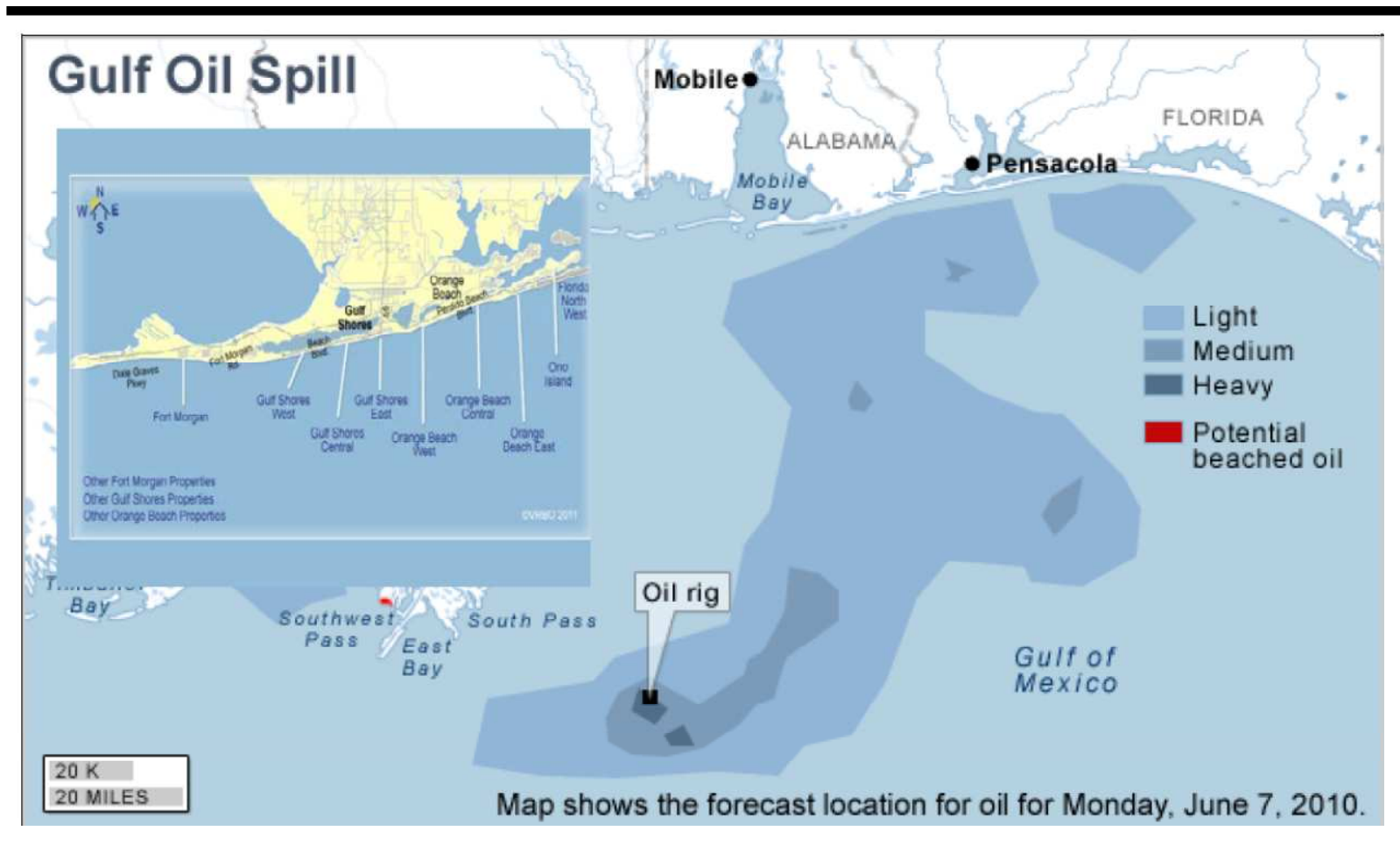

Note: Smaller map of Alabama coastline was inserted into larger map of Gulf of Mexico by the authors. Source: Google Images 